\title{
TECHNOLOGY AND CULTURE: FIVE ORTHODOXIES
}

\author{
AJ Grant, Robert Morris University, granta@rmu.edu \\ Robert Joseph Skovira, Robert Morris University, skovira@rmu.edu
}

\begin{abstract}
This paper explores contemporary perspectives on the relationship between technological innovation and culture. The paper reviews works that explore the relationship between culture, understood as human groups that exhibit "stable and enduring systems of meanings shared," and technology, the mechanical and digital extensions of human beings into the physical world for survival and control. In the paper we identify five typical ways that humans have attempted to articulate the relationship between these two complex realities.
\end{abstract}

Keywords: Culture, Technology, Information technology, Communication technology, Infoscape, Values.

\section{INTRODUCTION}

This paper explores contemporary perspectives on the relationship between technological innovation and culture. Technology is about doing things. Technology is about easily and quickly accomplishing a task or solving a problem. Technologies include devices or tools, physical or logical, that extend the abilities and capabilities of the tool user. Technology is thus the incarnation of ideas focused on particular ends-in-view and extends human reach in the world, affording ways of dealing with perceived constraints [5].

But technology does not exist in a vacuum, rather, technological ideas are incarnated within enduring and stable shared systems of meanings and objects [16; 40; 41]. A tool, device or process, is, in fact, a cultural artifact or object. A technological object represents a view of things and the world [21]. A tool is a sign $[21 ; 18]$ of a system of meanings at work. There is a dance between any technology and the cultural frame or system which surrounds it. A technological solution, a pen or word processing application, is a designed object. The notion of design suggests that a tool or device has been imagined and created in terms of ends-in-view, task, state of affairs, and situation. A tool is created to be used in a specific type of recurrent situation [35].

We are a networked society, a networked world, globalized by satellites orbiting above us, unheeded while they work [15]. There is a new and different "take" on the phrase: "webs of significance" [16] when used in the technological society. We develop drugs and vaccines, procedures and devices, which afford a certain freedom in furthering our reach in our existence here on this planet $[43 ; 44 ; 45]$. We develop new modes of communication that afford a certain freedom to converse when and where we want, not constrained by time, even time zones, or distance [39]. We develop new modes of transportation that afford a certain freedom to go where and when we want to go, not constrained by time or distance. Unlike Hansel and Gretel, we do not lack GPS devices.

We inhabit an Information Society [36]. Computers and digital devices reign, affording a certain freedom from the constraints of paper and books, extending our reach into our informational, conceptual, spaces. For many of us, these affordances show up in what we call information technology, used in communicating with others via email and text messaging, informing ourselves and others. Technology, in the guise of information technology, is changing our perspective on social and corporate responsibilities and obligations [37].

These new instrumentalities extend into the infoscapes (cultures) [38] of our societies and our organizations. They have a global reach [15]. When we began to write this essay, Venezuelan students were coordinating and informing us about their "rebellion” against technological society by texting messages and pictures via cell phones to comrades in the US [44; 47; 48]. This reach is not only about our use of information and knowledge, but also about what and how we teach. We educate people in the mysteries of information technology by using information technology. We are engaged in the dance of technology and culture [20]. We are the callers at a "hoe-down," but we are also the square-dancers. Given the complex interconnections of technology and culture, we should seek to understand this relationship of the two in the symbolic system that is information technology.

\section{PROBLEM OF THE PAPER}

Technology is a basic societal frame structuring experience: human intentionalities, acions, and endsin-view [17]. The problematic for the paper is how conceptions of technology via the instrumentalties of information technologies in use in the corporate and 
educational arenas provide a structure for human behavior. The paper addresses the interplay of conceptualizations of technology and culture, and then extends the conceptualizations to thinking about IT and education institutins and organizations generally, and more specifically online education and corporate activities.

\section{TECHNOLOGY - BIRTH OF A GOD TERM}

In 1901, Henry Adams [1] argued that the spiritual power of the Virgin Mary had been displaced by the Dynamo, the steam turbine engine. Neal Postman argues in a similar vein in The End of Education where he suggests that all cultures need gods, that is stories, and not just any story, rather "one that tells of origins and envisions a future, a story that constructs ideals, prescribes rules of conduct, provides a source of authority, and, above all, gives a sense of continuity and purpose” [33, p. 5]. A god in the sense Postman envisions, is "the name of a great narrative, one that has sufficient credibility, complexity, and symbolic power to enable one to organize one's life around it” [33, p. 6]. One of the authoritative stories, perhaps the authoritative story of our culture is the story of technology.

Postman, we believe, is talking about what Richard Weaver, in The Ethics of Rhetoric [42], called "ultimate terms," words and phrases that are packed with meaning that elucidate a culture's values and beliefs. Weaver argues that every culture ("which is not simply distraught") "manages to achieve some sort of relationship among the attractive and among the repulsive terms," and this enables members of the culture to identify a hierarchy of value within a culture [42, p. 212]. Weaver thus identifies god terms, devil terms and charismatic terms. God terms are names of entities "to which the very highest of respect is paid” [42, p. 212]. For example, Weaver identifies "modern," “efficient," and “American” as god terms in the 1950's and "communist" and "prejudiced” as devil terms [42, pp. 212-224]. Weaver also describes charismatic terms, terms which "have broken loose somehow and ... operate independently of referential connections" [42, p. 227], terms like "freedom," "progress" and "liberty," which are currently being recycled in the United States and associated with images that portray the terms. Contemporary god terms include "technology," "fact" and "American" and are also being associated with relevant images in the popular media. Moreover the words "Taliban" and "Al Qaeda” (and often "Islam” and "Muslim”) are on the road to becoming devil terms, "'terms of repulsion' that designate whatever is perceived as the enemy or the greatest evil in a culture” [13, p. 172]. In this paper, we wish to argue that technology has become an ultimate term - to some a god term, to others a devil term, but to all an ultimate term that signals power and influence [see also Marx, 21].

Finally, Kenneth Burke has argued that the modern edifice of science and technology has replaced (displaced) the Christian world view and inherited its symbolic power as a god, a higher power, since the underlying assumption is "the more technology, the higher the culture" [4, p. 71]. And because of the symbolic power of the Guilt/Redemption Cycle (read out of Augustine's Confessions and Gen 1-3), even secular Western culture continues the creation/fall drama (the search for Order) as well as a conversion model-the conversion from a life of sin to a life of righteousness developed initially in Augustine's Confessions and passed along through both the Catholic and Protestant traditions. Burke observes,

The resources of dialectic being what they are, one can make out a good case either for the thesis that modern science grew up outside the rationalizations of theology or for the thesis that modern science is but the translating of theology into a secular counterpart. [4, p. 170]

Burke is inclined to believe that science has translated religious language into its secular counterpart and that technology itself has become a religion since it sets cultural agendas and features itself as the highest priority:

Insofar as "technologism” is a "religion" (and it is a religion to the extent that technology is viewed as an intrinsic good, so that its underlying, unspoken assumption is: 'The more technology, the higher the culture'), we had better favor a calculus that keeps us always aware of technology's vast motivational cathedrals, and particularly such as Augustine's, which is so tirelessly concerned with problems of words and The Word. [4, p. 171]

Given these insights from Adams to Postman and Weaver to Burke, we will examine the ways [11; 12] in which a number of writers have conceived of the relationship between technology and culture, exploring the five orthodoxies listed below. And we use the term orthodoxy (right thinking or belief) intentionally, because people do form communities of belief that value (or devalue) technology and they do argue for the validity of their beliefs as a good Christian, Jew or Muslim might. Moreover, these communities of belief also require orthopraxy (right practice) on the part of its participants. True believers not only believe the right things but they also do the 
right things, that is, they behave in ways that reflect their faith commitment, and, of course, the check book (debit card?) is the most accurate measure of orthopraxy in the West.

\section{FIVE ORTHODOXIES}

We have adapted the five types from $\mathrm{H}$. Richard Niebuhr's Christ and Culture where Niebuhr [24] identifies five typical ways that the relationship between Christianity and culture has been articulated. Since technology functions as an ultimate term in the West, especially in the United States, substituting "technology" for "Christ" in each of Niebuhr's constructs yields a typology that elucidates people's perceptions of the complex and vexing relationship between technology and culture.

\section{Technology the Transformer of Culture}

Technology transforms culture in unforeseen and powerful, but generally positive ways. Examples include Lewis Mumford's Technics and Civilization [23] and Marshall McLuhan's Understanding Media [22]. Technology is often depicted as neutral in this view; it depends on what one does with it. Splitting the atom can either generate electricity for a large city or annihilate it. Any developed tool is context and value free [30]. No tool or device is in itself good or bad [2; 28].

Mumford's classic study of how the invention of the clock in the $12^{\text {th }}$ century by a monk in a monastery radically transformed western notions of time and space is a good example of this approach to the relationship between technology and culture. Marshall McLuhan's notion of technological innovation as "extensions" and amplifications of parts of the human body illustrate this approach as well. "Any invention or technology is an extension or self amputation of our physical bodies and so the extension also demands new ratios or new equilibriums among the other organs and extensions of the body" [22, p. 45]. McLuhan argues that humans shape tools and then the tools reshape humans and their cultures in unimaginable ways. "Physiologically, man in the normal use of technology...is perpetually modified by it and in turn finds ever new ways of modifiying his technology" [22, p. 46].

This deterministic view of technology is held by faculty at my university who see the new information technologies as inevitable and expect that the utilization of online shells, for example, will change the face of education in ways we cannot yet imagine. Whatever the changes, however, the end result will generally be viewed as positive.

\section{Technology Against Culture}

Technology attacks and eventually destroys culture and the term /technology/ is viewed as a devil term [14]. Jaques Ellul [9; 10], a Christian writer, sees technology displacing Christian culture and thus calls technology's "bluff” by adducing four principles of technological innovation:

- $\quad$ First, all technical progress has its price.

- $\quad$ Second, at each stage it raises more and greater problems than it solves.

- Third, its harmful effects are inseparable from its beneficial effects.

- Fourth, it has a great number of unforeseen effects. [10, p. 39]

Since Technical progress has no telos, it "does not know where it is going” [10, p. 39], and is therefore unpredictable in terms of its consequences.

Similarly, Neal Postman, in Technopoly, argues that the U.S. has become a technopoly, a culture where one finds "the submission of all forms of cultural life to the sovereignty of technique and technology" [34, p. 52]. Disastrous effects follow. Humans, as Nietzsche once argued, are cut off from their cultural stories that tell them of origins and destiny [25]. Though once a "tool-using" culture and later a "technocracy," the United States has become the first "technopoly" whose very history, originality, and humanity is being challenged by devotion to technique and technology. Postman believes that we can be saved only by becoming "loving resistance fighters” [34, pp. 182 ff.] who call into question and critique every so-called technical advance and innovation.

At my university, faculty who refuse to use Email, Power Point, Smart Boards or an online shell for a course, would illustrate this view of the relationship between culture and technology. Any and all technological innovation is considered evil.

\section{The Technology of Culture}

Technology is culture or a natural outgrowth of culture. James Beniger [3] argues that the Information Age is a natural outgrowth of the Industrial Age. As the genetic code is a natural and necessary component of evolution and natural selection, even so the growth of information technologies, the centerpiece of the control revolution, is a necessary and natural outgrowth of the industrial revolution. For Beniger, the current explosion of information technologies is a natural and necessary complement of the ability to extract raw materials quickly, process them and distribute them to people in the industrial nations during the late nineteenth and early twentieth centuries. Information 
is absolutely necessary to control the extraction, production and distribution of goods through and throughout industrialized nations. The purpose of education, law and government is to program people into the ways of the information society [3]. In this view of technology and culture, technology is culture, and instead of attacking culture, makes culture possible.

Faculty who embrace this approach to the relationship between technology and culture integrate new technologies into their pedagogy where the innovation complements and enhances their teaching. This position attempts to reconcile the radical position of the neo-Luddite (technology against culture) and the technophile (technology above culture) by wondering what the fuss is all about.

\section{Technology above Culture}

In this view, /technology/ is a god term and technology is a god. All technological innovation is conceived of as progress and responsible for moving a culture toward an increasingly prosperous and efficient life. This approach is illustrated by the ready acceptance of technological innovation by most Americans who reject the three positions already discussed and treat technology as a good god with good gifts. Hundreds of popular journals and books that populate the shelves of popular bookstores illustrate this approach. For example, magazines such as Wired and Fast Company feature stories that are about all the latest and newest gadgets and advertisements that extend the value of the product to the purchase of it.

This is perhaps the least reflective of the orthodoxies described in this paper and perhaps the most prevalent. Faculty and staff who seek to bend pedagogy to fit the new technologies belong to this group. Claims about technology tend to be exaggerated. Ones teaching is not just enhanced by the technology but improved. For these lovers of technological innovation, any communication medium (email, online shell, etc.) is virtually the same as Face-to-Face (F2F) communication.

The "Technology above Culture" model seems to us the most dangerous because of its patently false assumptions:

1) All communications/information media are good and should be adopted and adapted for educational use.

2) Tacit (or silent) knowledge is not important since it cannot be communicated through electronic media and simulation. The same goes for spoken language and body language. F2F communication should not be granted a privileged status among communications media.

3) All communications/information media are the same, possessing virtually the same epistemology and ontology.

4) Simulation of an activity is as good as the activity itself.

\section{Technology and Culture in Paradox}

Technology and culture stand in a paradoxical relation to each other. This position adopts the technological innovation but also seek to preserve the culture. The relationship between technology and culture is not simple, and one should neither reject technological innovation outright nor accept it unconditionally, rather the two realities must be reconciled in some fashion in every culture in order to fashion a good and just world. Scholars like Thomas B. Hughes, Human Built World: How to Think about Technology and Culture [19] and David Nye, America as Second Creation [26] and Technology Matters [27] illustrate this approach. Umberto Eco's $[6 ; 7 ; 8]$ humorous essays collected in How to Travel with a Salmon reflect this approach as does Andrew Feenburg's hermeneutical, social constructionist approach [11, 12].

This, we confess, is our approach. Just because IPods exist does not mean that we upload our lectures to podcasts and expect students to use the medium for this purpose [35]. Just because online shells exist does not mean that we should develop fully online programs of study. For higher education, new information technologies should be analyzed in light of a philosophy of education and implemented if the technology serves a relevant end articulated in this philosophy.

\section{CONCLUSION}

The term /technology/ has clearly become an ultimate term in the United States. For some it is a god term, for others a devil term, and many still wonder what the fuss is all about. Information technologies are transforming the culture of the U. S. The internet, video games, IPods, cell phones and PDAs are reshaping the information landscapes of our lives. This paper attempts to delineate a typology for explaining people's perceptions about the relationship between culture and technology in an effort to encourage thoughtful dialogue and debate about the uses of IT innovations in higher education. Plato's 2,400 year old idea of dialectic suggests an ongoing dialogue between student and teacher that can be enhanced through information technology, but not superseded. A variety of metaphors attributed to Socrates suggests a rich, interpersonal relationship between student and teacher. Socrates presents the 
teacher as a midwife in the Theatetus [31, pp. $31 \mathrm{ff}$. suggesting that the student already possesses knowledge but has forgotten that he or she knows it. The teacher thus assists the students in giving birth to the knowledge already possessed. The teacher is also presented as a gadfly (32, pp. $113 \mathrm{ff}$.$] , which stings$ the student into action through provocation and pain. Later in the Apology, Socrates pictures himself as awakening the student out of a deep slumber [32]. These metaphors suggest an active, engaged relationship between students and teacher. Finally, what are we to make of the fact that Socrates and Plato both mistrusted the latest IT innovation of the day-writing - Socrates wrote nothing and Plato preferred the power of the spoken word, referring derisively, we suspect, to his student, Aristotle, as the “reader” and "writer” [29, pp. 80 ff.].

\section{REFERENCES}

1. Adams, H. (1901). The education of Henry Adams. Project Gutenberg Reprint. Available at www.gutenberg.org.

2. Barbour, J. (1993). Ethics in an age of technology, vol. 2. New York: HarperCollins.

3. Beniger, J. (1986). The control revolution: Technological and economic origins of the information society. Cambridge, MA: Harvard University Press.

4. Burke, K. (1961). The rhetoric of religion. Berkeley, CA: University of California press.

5. Dusek, V. (2003). Philosophy of technology: The technological condition: An anthology (Blackwell Philosophy Anthologies). London, England: Blackwell.

6. Eco, U. (1992/1994a). How not to know the time. How to travel with a salmon and other essays. Translated by William Weaver. San Diego: Harcourt, 56-59.

7. Eco, U. (1992/1994b). How not to use the cellular phone." How to travel with a salmon and other essays. Translated by William Weaver. San Diego: Harcourt, 154-157.

8. Eco, U. (1992/1994c). How to travel with a salmon. How to travel with a salmon and other essays. Translated by William Weaver. San Diego: Harcourt, 5-8.

9. Ellul, J. (1964). The technological society (J. Wilkinson, Trans.). New York: Vintage Books.

10. Ellul, J. (1990). The technological bluff. Grand Rapids, MI: Eerdmans.
11. Feenburg, A. (1999). Questioning technology. Routledge

12. Feenburg, A. (2005). Transforming technology: A critical theory revisited, $2^{\text {nd }} E d$. Oxford: Oxford University Press.

13. Foss, S; Foss, K. \& Trapp, R. (1991). Contemporary perspectives on rhetoric. (Second Edition) Prospect heights, IL: Waveland Press.

14. Fox, N. (2002). Against the machine: The hidden Luddite tradition in literature, art, and individual lives. Washington: Island Press.

15. Friedman, T. L. (2000). The Lexus and the olive tree. New York: Farrar, Straus and Giroux.

16. Geertz, C. (1973). The interpretation of cultures. New York: Basic Books.

17. Goffman, E. (1974). Frame analysis: An essay on the organization of experience. Cambridge: Harvard University Press.

18. Haraway, D. J. (1999). Modest_witness@second_millennium. In D. MacKenzie \& J. Wajcman (Eds.), The social shaping of technology, $2^{\text {nd }}$ ed (pp. 41-49). Buckingham \& Philadelphia: Open Humanity Press.

19. Hughes, T. B. (2004). Human built world: How to think about technology and culture. Chicago: University of Chicago Press.

20. Jaspers, K. (1953). The Origin and Goal of History. New Haven and London: Yale University Press.

21. Marx, L. (1997, Fall) Technology: The emergence of a hazardous concept. Social Research 64(3), 965-988.

22. McLuhan, M. (1964). Understanding media: The extensions of man. Cambridge, MA: MIT Press Edition (1994).

23. Mumford, L. (1934). Technics and civilization. New York: Harcourt, Brace and Company.

24. Neibuhr, H. R. (1951). Christ and culture. New York: Harper and Row.

25. Nietzsche, F. (1956). The birth of tragedy (F. Goeffing, Trans.). New York: Doubleday.

26. Nye, D. (2004). America as Second Creation: Technology and narratives of new beginnings. Cambridge, MA: MIT Press.

27. Nye, D. (2006). Technology matters: Questions to live with. Cambridge, MA: MIT Press. 
28. Ojeda, A. (Ed.) (2002). Technology and society: Opposing viewpoints. San Diego, CA: Greenhouse Press.

29. Org, W. (1982). Orality and literacy. London: Routledge.

30. Pacey, A. (1983). The culture of technology. Cambridge, MA: The MIT Press.

31. Plato. (1937). Theaetatus (Fowler, H. N., Trans.). Loeb Classical Library 123.

32. Plato. (1914). Apology (Fowler, H. N., Trans.). Loeb Classical Library 36.

33. Postman, N. (1996). The end of education. New York: Vintage

34. Postman, N. (1993). Technopoly: The surrender of culture to technology. New York: Random House.

35. Rothenberg, D. (1993). Hand's end: Technology and the limits of nature. Berkeley: University of California Press.

36. Skovira, R. J. (2002). A Conception of Information for a Postmodernist Information Science. Kniznicna a Informacna Veda XIX. Bratislava, Slovakia: Comenius University.

37. Skovira, R. J. (2003). The social contract revised: Obligation and responsibility in the information society. In R. Azari (Ed), Current security management and ethical issues of information technology (pp. 165-186). Hershey, PA: IRM Press.

38. Skovira, R. J. (2004). Using informational landscape as a model to understand information use and design within organizations. Issues in information Systems, V(1): 308-314.

39. Totterdale, R. \& Skovira, R. J. (2007).. First and last things: Understanding communication and organizational infoscape. Issues in Information Systems VIII (2), 39-44.

40. Trompenaars, F. (1994). Riding the waves of culture: Understanding diversity in global business. London: The Economist Books.

41. Trompenaars, F. \& Woolliams, P. (2003). Business across cultures. Chichester, England: Capstone Publishing.

42. Weaver, R. (1953). The Ethics of Rhetoric. South Bend, Indiana: Gateway.

43. Willinsky, J. (1999). Technologies of knowing: A proposal for the human sciences. Boston: Beacon Press.
44. Winner, L. (1977). Autonomous Technology: Technics-out-of-Control as a Theme in Political Thought, Cambridge, MA: M.I.T. Press, 1977.

45. Winner, L. (1986). The Whale and the Reactor: A Search for Limits in an Age of High Technology, Chicago, IL: University of Chicago Press.

46. Winner, L. (Ed.). (1992). Technology and Democracy. Dordrecht and Boston: Reidel/Kluwer.

47. Winner, L., Feenberg, A. \& Nielsen, T. H. (Eds.). (1997). Technology and Democracy: Technology in the Public Sphere. Oslo: Center for Technology and Culture.

48. Winner, L. (1999). Do artifacts have politics? In D. MacKenzie \& J. Wajcman (Eds.), The social shaping of technology, $2^{\text {nd }}$ ed (pp. 28-40). Buckingham \& Philadelphia: Open Humanity Press. 